\title{
Monitoring Indicators of Harmful Cyanobacteria in Texas
}

\section{Harmful Algal Blooms}

Harmful algal blooms (HAB) can occur when certain types of microscopic algae grow quickly in water, forming visible patches (for example, fig. 1) that might harm the health of the environment, plants, or animals (Centers for Disease Control and Prevention, 2004). In freshwater, species of Cyanobacteria (also known as bluegreen algae) are the dominant group of harmful, bloom-forming algae (Sinclair, Hall, and others, 2007). When Cyanobacteria form a harmful algal bloom (C-HAB), potential impairments include restricted recreational activities because of algal scums or algal mats, potential loss of public water supply because of taste and odor compounds (for example, geosmin), and the production of toxins (for example, microcystin) in amounts capable of threatening human health and wildlife (Centers for Disease Control and Prevention, 2004; Graham, 2006).

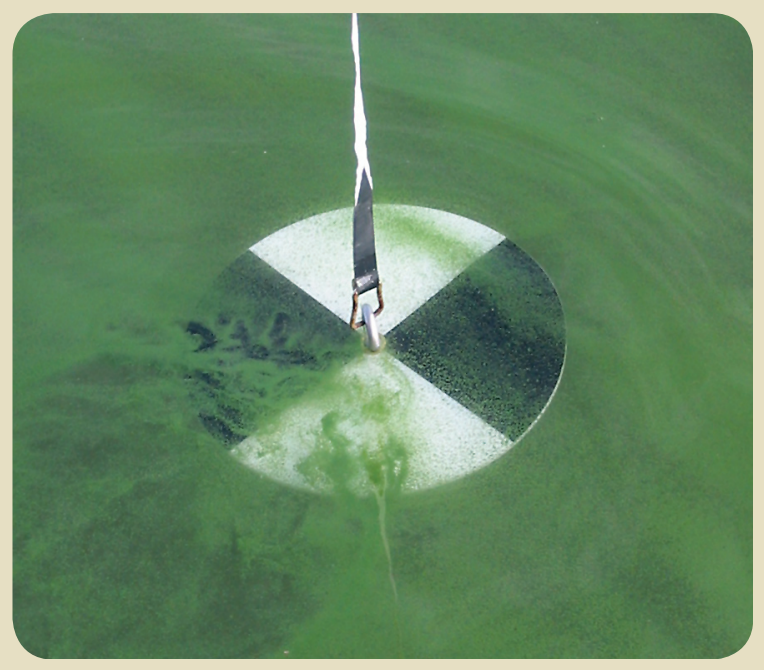

Figure 1. Surface algal bloom of Cyanobacteria (Anabaenopsis circularis) on Waco Lake, Texas, March 2005.

The risks C-HABs pose to source water and public health prompted the U.S. Environmental Protection Agency (USEPA) to add freshwater algal toxins from Cyanobacteria (cyano-toxins) to the USEPA drinking-water contaminant candidate list in 1998 (U.S. Environmental Protection Agency, 1998). The World Health Organization also set a drinking-water guideline for the cyano-toxin microcystin-LR of 1 microgram per liter (Chorus and Bartram, 1999; World Health Organization, 2006). In addition to cyano-toxins, Cyanobacteria also are a source of the taste and odor compounds geosmin and methyl-isoborneol (MIB) (Chorus and Bartram, 1999). Together, these compounds and cyano-toxins have the potential to degrade source-water quality and impair public water-supply uses of surface water.

\section{Cyanobacteria Monitoring Capabilities}

The U.S. Geological Survey (USGS), with cooperators, has developed capabilities to study cyanobacterial blooms and their associated toxins as well as taste and odor compounds (fig. 2). Some of these capabilities follow:

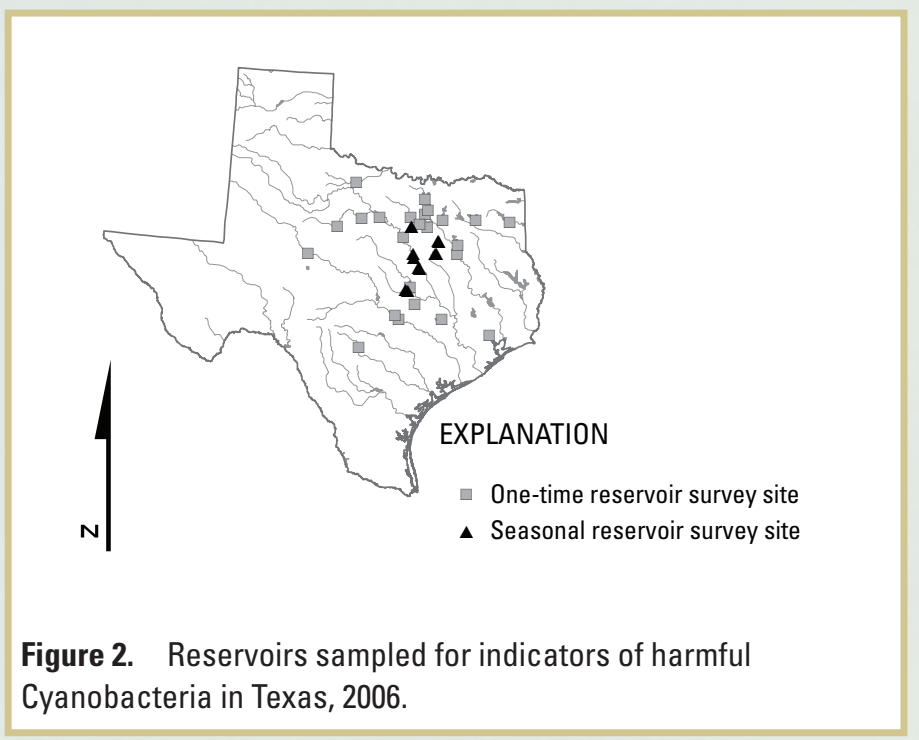

\section{Reservoir Monitoring}

Regional reservoir surveys are done to evaluate the distribution and abundance of bloom-forming algae and allow for the tracking of algal blooms to estimate their persistence and spatial extent. Additionally, sampling for nutrients and other constituents of interest are done to evaluate correlations between water quality and C-HABs.

\section{Continuous Monitoring}

Multiple-depth water-quality monitors track physical and chemical properties that might be associated with algal blooms over multiple time scales. Experimental in vivo fluorescence (IVF) chlorophyll probes are used for tracking algal biomass and Cyanobacteria occurrence. In Texas, research is being done in cooperation with the U.S Army Corps of Engineers, the City of Houston, and the City of Waco to evaluate the ability of continuous data to predict the concentration of chlorophyll, Cyanobacteria, MIB, and other HAB-related compounds in surface water. This type of information is delivered by the USGS National Water Information System (NWISWeb) (U.S. Geological Survey, 2008) for continuous monitoring of algal bloom dynamics.

\section{Ecological Data Collection}

Limiting nutrient algal growth-rate bioassays are done to assess bloom regulation and nutrient limitation. Results from phytoplankton analysis yield algal biomass estimates and algal species composition to document algal bloom characteristics.

\section{Investigation of Biological Constituents of Concern}

Cyano-toxins and taste and odor compounds analyzed at the USGS Organic Chemistry Research Laboratory in Lawrence, Kan., are used to track reservoir source-water quality and evaluate linkages between environmental conditions and $\mathrm{C}-\mathrm{HAB}$ occurrence. 


\section{Monitoring Activities}

In cooperation with the Texas Commission on Environmental Quality, 36 sites at 30 reservoirs (six reservoirs had two sites each) across Texas were each sampled once during 2006 as part of a study to assess the linkage between Cyanobacteria abundance and C-HAB indicators including microcystin, geosmin, and MIB (fig. 2). A subset of the six reservoirs with two sites each also were sampled at various times during 2006 to evaluate the seasonal nature of these linkages. Data collected during the study were entered into a geodatabase for spatial analysis. The geodatabase framework allows for spatial analyses of field data, laboratory results, and environmental data by relating site locations to data tables (fig. 3). A geodatabase query linking the site, sample, and tables of laboratory results was done to determine the number of detections recorded at source-water reservoirs. The outcome of the query is expressed as a map with graduated symbols representing the number of detections for the one-time reservoir survey sites and for the seasonal reservoir survey sites.

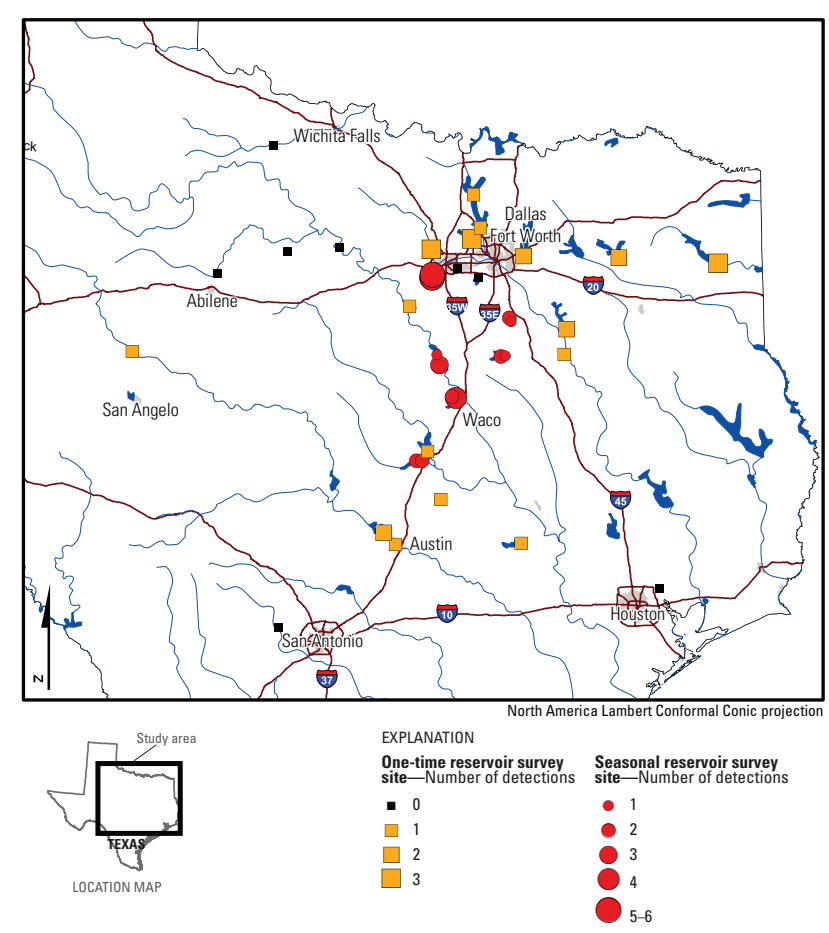

Figure 3. Number of detections of geosmin, methyl-isoborneol, and microcystin at the 36 reservoir sites sampled during 2006.

Over the years, monitoring of algal populations using traditional methods has identified a number of Texas reservoirs with potentially harmful Cyanobacteria. Since 2006, real-time, in-lake chlorophyllfluorescence monitoring using an IVF sensor has provided valuable information for tracking algal bloom formation. Inferred chlorophyll concentrations from the IVF sensor have been used to identify potential algal blooms and to track temporal patterns in algal biomass distribution. For example, continuous real-time data collected during 2006 at Whitney Lake and at Waco Lake identified periods when potential algal blooms were developing. In the case of Whitney Lake, peaks in inferred chlorophyll concentration (fig. 4) were used to indicate when to begin water-quality monitoring, which involved integrating traditional sampling methods with modern sensor technology. Current (2008) real-time data from Waco Lake are available on the USGS NWISWeb at http://waterdata.usgs.gov/tx/nwis/ uv/?site_no=313430097113801

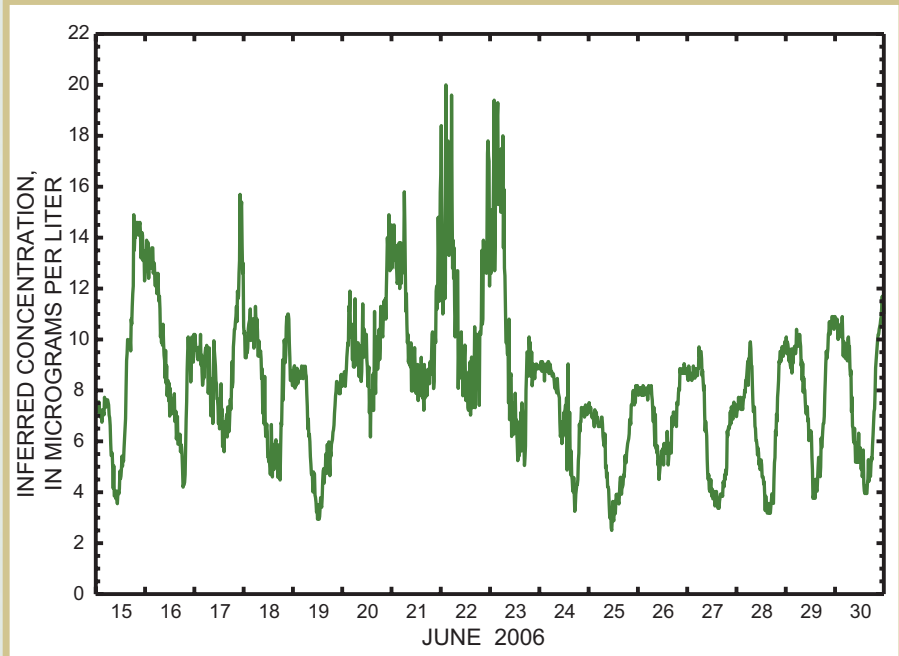

Figure 4. Chlorophyll concentrations at Whitney Lake, Texas, inferred from in vivo fluorescence (IVF) measured by an inlake, real-time IVF sensor. Peaks show a pattern of increasing chlorophyll concentrations associated with a developing algal bloom during June 20-23.

\section{References}

Centers for Disease Control and Prevention, 2004, Harmful algal blooms: Department of Health and Human Services, Centers for Disease Control

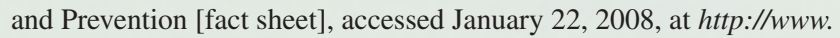
cdc.gov/hab/pdfs/factsheet.pdf

Chorus, Ingrid, and Bartram, Jamie, eds., 1999, Toxic Cyanobacteria in water: New York, E\&FN Spon, 416 p.

Graham, J.L., 2006, Harmful algal blooms: U.S. Geological Survey Fact Sheet 2006-3147, 2 p.

Sinclair, J.L., Hall, S.H., and others, 2007, Chapter 3-Occurrence of cyanobacterial harmful algal blooms workgroup report, in Hudnell, H.K., ed., International Symposium on Cyanobacterial Harmful Algal Blooms (ISOC-HAB), Research Triangle Park, N.C., 2005, Proceedings: accessed January 22, 2008, at http://www.epa.gov/cyano_habs_ symposium/monograph.html

U.S. Environmental Protection Agency, 1998, Announcement of the drinking water contaminant candidate list: Federal Register, v. 63, no. 40, p. $10,273-10,287$.

U.S. Geological Survey, 2008, National Water Information System (NWISWeb) data available on the World Wide Web at http://waterdata. usgs.gov/nwis

World Health Organization, 2006, Guidelines for drinking-water quality, third edition, incorporating first addendum-Volume 1. Recommendations: Water Sanitation and Health, accessed January 22, 2008, at http://www.who.int/water_sanitation_health/dwq/gdwq3rev/en

—Richard L. Kiesling, Robin H. Gary, and Marcus O. Gary

Any use of trade, product, or firm names is for descriptive purposes only and does not imply endorsement by the U.S. Government.

\section{For additional information, contact}

Director

USGS Texas Water Science Center

World Wide Web: http://tx.usgs.gov/

E-mail: gs-w-txpublic-info@usgs.gov 